\title{
Structure and Distribution of the Glandular Hairs on the Chamomile Florets in Relation to Essential Oil Composition and Quality under Application of Ethrel and $\mathrm{GA}_{3}$
}

Arafa, A. A.

Botany Department, Faculty of Agriculture, Mansoura University.

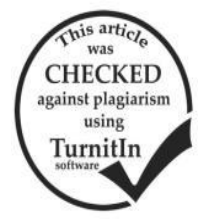

\section{ABSTRACT}

A field experiment was carried out to study the effect of Ethrel and $\mathrm{GA}_{3}$ on the essential oil composition as well as distribution pattern and structural and morphological features of the glandular trichomes secreting the essential oil from the flower heads of chamomile plant.The applied treatments showed a promotive effect on the chamazulene production that represents the most important medical component in the chamomile essential oil.

\section{INTRODUCTION}

All over world, the drug, spice and volatile oil plant production has increased during the last decades. Among these crops wild chamomile (Matricaria recutita $\mathrm{L}$.) is of the most important one in this respect.

Matricaria recutita $\mathrm{L}$. is one of the medicinal plants that have maintained a firm place in medical therapy. The spasmolytic and antiphlogistic properties of the drugflores chamomillae-have been traced to the presence of various sesquiterpenes unsaturated polyacetylene compounds and flavonoids (Isaac, 1974). The increasing demand for medicinal herbs for the pharmaceutical industry has led to greater dependence on cultivated plant material so as to guarantee sufficient supplies of raw material for the industry (Reichling et al., 1978).

The development of the yield and change of the content in the essential oil of chamomile were the object of several investigations (Schantz and Salonen, 1966). Further findings about the substance spectrum of the chamomile oil and its distribution within the flower heads (Isaac, 1974, Hoelzl and Demuth, 1975) made it necessary to study again the content and composition of essential oil during the flowering period. These examinations should help to determine a favourable harvest time and the most suitable growth regulator with respect to the quality of the chamomile drug.

Furthermore, it appeared most important to investigate the effect of growth regulators on the glandular structures in chamomile plant to explain any change in the essential oil composition and its relation to the number of glands and/or their productivity.

\section{MATERIALS AND METHODS}

Plant materials and growth regulators :

Seeds (fruits) of Matricaria recutita L. var. E40 were secured from the Experimental Station, Schloss Rauischolzhauser, Ebsdorfergrund 4, Germany. Two growth regulators were used in the current investigation namely gibberellic acid $\left(\mathrm{GA}_{3}\right)$ and Ethrel.

Minimum $90 \% \mathrm{GA}_{3}$ was obtained as powder active ingredient from the chemical Company Sigma. The four concentrations : 0 (control), 75, 150 and 300 $\mathrm{mg} / \mathrm{L}$ were used for spray application using distilled water.

Ethrel (ethephon; CEPA; Florel; Flordimex) was obtained from Pflauzenschutz URANIA $\mathrm{GmbH}$, Alsterufer 20, Hamburg, Germany. It was 474 g/L, a.i. ethephon, aqueous solution. The four concentrations : 0 (control), 300, 600 and $1200 \mathrm{mg} / \mathrm{L}$ were used also as spray application using distilled water. A surfactant (Tween 20) was added to the growth regulator solutions at the rate of $2 \mathrm{ml} / \mathrm{L}$.

The different concentrations of the two growth regulators were applied at the pre-flowering stage (76 days old).

Seeds (fruits) were sown on March $21^{\text {st }}$ in the greenhouse; the seedlings were planted into small pots after 20 days and later transplanted to the permanent site into the experimental field at the age of 46 days.

The plants were fertilized at the age of 56 days with wuxal $(2 \mathrm{ml}$ concentrated solution per liter water, of this solution $200 \mathrm{ml}$ per plant were given.

The experimental design was a split plot. The experimental unit dimensions were $1.2 \times 1.2 \mathrm{~m}$ and the treated plants for each plot were surrounded by a row of guard plants from all directions. The plant stands were spaced at $30 \times 30 \mathrm{~cm}$.

\section{Recording of data :}

Four plants representing each treatment were assigned for recording data. Data were recorded on individual plants with respect to flower head study.

Keeping the samples of essential oils :

The essential oil samples were dehydrated by anhydrous sodium sulphate and kept in test-tubes with polyacetylene stoppers at $2-4{ }^{\circ} \mathrm{C}$ under light protection after solving in acetic acid ethylester $\left(\mathrm{C}_{4} \mathrm{H}_{8} \mathrm{O}_{2}\right)$. Later, they were examined by means of gas chromatography for which from each growth regulator was chosen only the previously mentioned concentration which gave the maximum flower yield (unpublished).

The GLC conditions were : column $1.8 \mathrm{~m} / 2 \mathrm{~mm}$ filled with $2 \%$ OV-7. Temperature programme : $100-220{ }^{\circ} \mathrm{C}$ : $10{ }^{\circ} \mathrm{C} / \mathrm{min}$. Injector temperature : $250{ }^{\circ} \mathrm{C}$, detector temperature : $300{ }^{\circ} \mathrm{C}$ with $\mathrm{H}_{2}$ carrier gas at $40 \mathrm{ml} / \mathrm{min}$.

Histological examination :

Bromination; the dried tubular florets from the previously mentioned treatment for each growth regulator which was used for GLC analysis at the fifth collection were brominated during $3 \mathrm{hr}$ with $10 \mathrm{ml} 10 \%$ bromine solution in chloform by which the tubular florets are exposed to bromine vapours. The florets were examined by means of a stereo-microscope under a fourty-fold magnification. The glands appear dark blue in colour due to the oxidation of prochamazulene to chamazulene. The prochamazulene-free glands remain colourless or yellowish in colour. The blue glands are 
then counted under the microscope. The experiment was done on about 200 florets and the average number of the blue glands per floret (prochamazulene value) was deduced as follows : (Lassanyi et al., 1978)

Total number of blue glands

Prochamazulene value $=$

Number of examined florets

Reaction with permanganate : The fresh flowers (legulate and tubular) from all treated and untreated plants at the fifth collection were investigated. They were kept in $1 \%$ potassium permanganate solution for 10 min., the excess of the reagent then was washed with water, and the flowers were mounted in aqueous glycerin. The preparations were examined with a Leitz research microscope (Lassanyi et al., 1978).

\section{RESULTS AND DISCUSSION}

Essential oil composition during the flowering period: (-)-a-Bisabololoxide A :

In the untreated plants the content of the main component (-)- $\alpha$-bisabololoxide A increased gradually in the course of flowering and reached its maximum value at the $5^{\text {th }}$ collection, followed by a significant decrease during the cessation of flowering. In the treated pants, Ethrel did not affect the $\alpha$-bisabololoxide $A$ content at the $3^{\text {rd }}$ collection but afterwards decreased it significantly in the course of flowering at all others, and the reduction increased with the progress in the plant development towards the termination of flowering period.

Compared with the untreated plants, $\mathrm{GA}_{3}$ did not exhibit any significant difference in the $\alpha$ bisabololoxide $\mathrm{A}$ content at both the $3^{\text {rd }}$ and $4^{\text {th }}$ collections but the content decreased slightly at the $5^{\text {th }}$ collection followed by significant increase during the termination of flowering.

Table 1. Proportion of sesquiterpenes in the flower essential oil during the flowering period of chamomile plant as affected by Ethrel and $\mathrm{GA}_{3}$ (percentage of the compound in the essential oil).

\begin{tabular}{|c|c|c|c|c|c|c|}
\hline $\begin{array}{l}\text { Treatmen } \\
\text { mg/L }\end{array}$ & $\begin{array}{c}\text { No. } \\
\text { of } \\
\text { collection }\end{array}$ & Farnesene & $\begin{array}{c}\alpha- \\
\text { Bisabolol }\end{array}$ & Azulene & $\begin{array}{c}\alpha- \\
\text { Bisabolol } \\
\text { oxide A }\end{array}$ & ISpiroether \\
\hline \multirow{4}{*}{$\begin{array}{l}\text { Control } \\
\text { (0) }\end{array}$} & 3 & 7.1 & 3.4 & 9.2 & 60.8 & 14.8 \\
\hline & 4 & 6.7 & 2.8 & 5.2 & 62.9 & 18.6 \\
\hline & 5 & 5.1 & 2.9 & 3.6 & 64.8 & 19.1 \\
\hline & 6 & 4.8 & 3.7 & 2.9 & 53.9 & 24.7 \\
\hline \multirow{4}{*}{$\begin{array}{l}\text { Ethrel } \\
300\end{array}$} & 3 & 6.0 & 3.7 & 3.4 & 63.1 & 19.5 \\
\hline & 4 & 6.5 & 6.6 & 3.9 & 57.5 & 20.4 \\
\hline & 5 & 10.0 & 5.8 & 3.7 & 47.9 & 26.1 \\
\hline & 6 & 16.4 & 17.1 & 2.7 & 34.8 & 24.2 \\
\hline \multirow{4}{*}{$\begin{array}{l}\mathrm{GA}_{3} \\
75\end{array}$} & 3 & 10.6 & 2.8 & 0.9 & 59.3 & 20.4 \\
\hline & 4 & 7.0 & 2.4 & 5.2 & 62.4 & 17.9 \\
\hline & 5 & 6.9 & 1.7 & 5.3 & 60.0 & 21.4 \\
\hline & 6 & 3.3 & 2.0 & 2.0 & 64.3 & 19.7 \\
\hline
\end{tabular}

Chamazulene :

In the course of the flowering period the content of chamazulene in the untreated plants decreased gradually from the highest value at the early flowering period $\left(3^{\text {rd }}\right.$ collection).

Ethrel decreased significantly the content of chamazulene at the $3^{\text {rd }}$ collection while it did not produce any significant change at all the others compared with the untreated plants.

$\mathrm{GA}_{3}$ decreased significantly the chamazulene content at the $3^{\text {rd }}$ collection but showed no significant difference at the fourth. Afterwards it increased slightly though significantly the chamazulene content at the $5^{\text {th }}$ collection, and showed no effect at the end of flowering period as compared to the untreated plants.

\section{(-)- $\alpha$-Bisabolol :}

In the course of flowering the content of $\alpha$ bisabolol did not undergo significant changes in the untreated plants. With regard to the treated plants, Ethrel had no significant effect on the content of $\alpha$ bisabolol at the $3^{\text {rd }}$ collection but increased it gradually in the course of flowering and achieved the maximum value during the cessation of flowering.

$\mathrm{GA}_{3}$ did not exhibit any significant changes in the $\alpha$-bisabolol content during the whole course of flowering.

\section{Farnesene :}

The content of farnesene in the essential oil of the untreated plants decreased gradually in the course of the flowering period. With regard to the treated plants, Ethrel had no significant effect on the content of farnesene at both $3^{\text {rd }}$ and $4^{\text {th }}$ collections but increased it markedly at the $5^{\text {th }}$ as well as during the termination of flowering.

$\mathrm{GA}_{3}$ showed a wide range of activity in the course of flowering compared with the untreated plants. It increased significantly the content of farnesene at the $3^{\text {rd }}$ collection but had no effect at the $4^{\text {th }}$. Afterwards it increased again significantly the farnesene content at the $5^{\text {th }}$, and at the late collection reduced significantly the content of farnesene in the essential oil.

\section{Spiroether :}

In the course of flowering the content of spiroether in the essential oil of the untreated plants increased gradually towards the termination of flowering. Ethrel showed variable activity in the course of flowering. It increased significantly the content of spiroether at both the $3^{\text {rd }}$ and $5^{\text {th }}$ collections but had no effect at both the $4^{\text {th }}$ and $6^{\text {th }}$ compared with the untreated plants.

$\mathrm{GA}_{3}$ showed variable activity according to the time of collection. It increased significantly the content of spiroether in the essential oil at the $3^{\text {rd }}$ collection, while did not exhibit any significant effect at both the $4^{\text {th }}$ and $5^{\text {th }}$ collections, and decreased significantly the spiroether content during the cessation of flowering.

Since chamazulene is considered as the most important constituent determining the quality of chamomile oil, it appears that the two applied growth regulators either Ethrel or $\mathrm{GA}_{3}$ were not able to improve the oil quality. The lowering of the chamazulene content was found only at one collection date, viz. with Ethrel and $\mathrm{GA}_{3}$ at the $3^{\text {rd }}$ collection.

\section{Histological examinations :}

\section{Prochamazulene value at the $5^{\text {th }}$ collection :}

It was clear from Table (2) that the two applied growth regulators in this investigation either Ethrel or $\mathrm{GA}_{3}$ did not cause any marked increase of prochamazulene value at the $5^{\text {th }}$ collection compared with the untreated plants. 
Table 2. Prochamazulene value in the tubular florets of chamomile plant at the $5^{\text {th }}$ collection as affected by Ethrel and $\mathbf{G A}_{3}$. (Means of 200 tubular florets).

\begin{tabular}{lc}
\hline Growth regulator $\mathbf{~ m g} / \mathbf{L}$ & Prochamazulene value \\
\hline Control 0 & 2.4 \\
Ethrel 300 & 2.3 \\
$\mathrm{GA}_{3} \quad 75$ & 3.0 \\
\hline
\end{tabular}

(a)

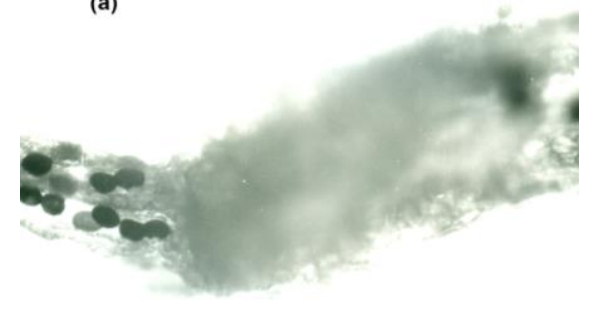

$\mathrm{GA}_{3}$ showed a slight increase whereas Ethrel had no effect in this regard. It seemed, therefore, desirable to examine whether the variation in chamazulene value was related to changes in the distribution of the chamazulene-bearing glandular hairs. In the untreated plants, these glandular hairs are arranged in vertical rows on the surface of the ovary, and randomly scattered on the surface of the corolla (Figs. $1 \mathrm{a}$ and b). This pattern was not changed by any of the treatments.

(b)

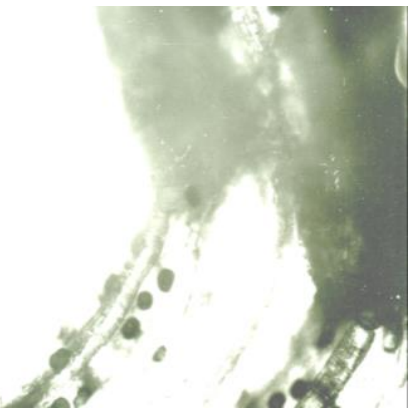

Fig. 1. Distribution of the prochamazulene glandular hairs on the tubular floret in the untreated plants of chamomile.

a) The glands are arranged in lines (x100).

Morphology of the glandular hairs :

The microscopical examination did not show any differences among all the treated and untreated plants at the $5^{\text {th }}$ collection regarding the general structure of the b) The glands are scattered on the surface (x100). glandular hairs at both tubular and ligulate florets. The glandular hairs either in treated or untreated plants were similar and consisted of eight cells arranged in two vertical rows (Figs. 2 and 3). (a)

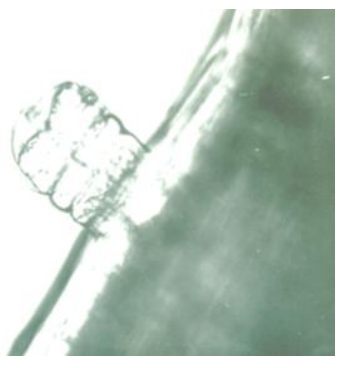

Fig. 2. Development of chamomile glandular hair on tubular floret (x400).

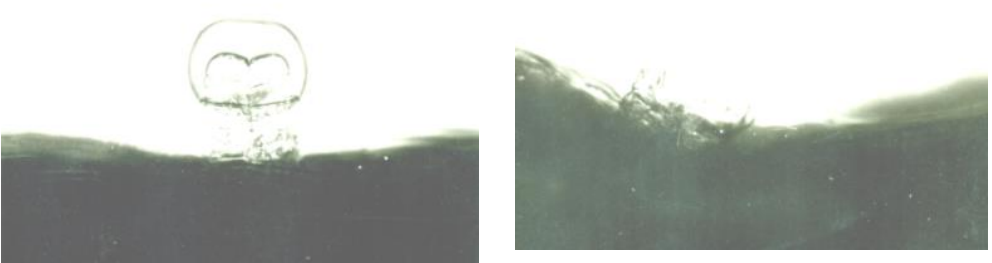

b) More developed glandular hair. c) Fully developed glandular hair.

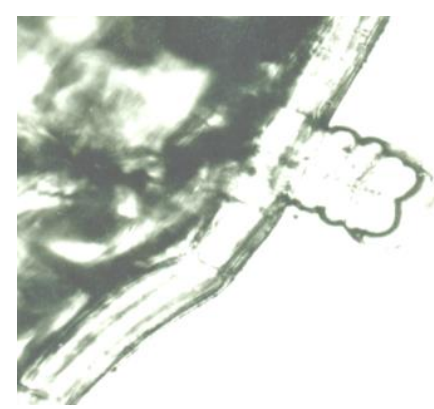

(a)

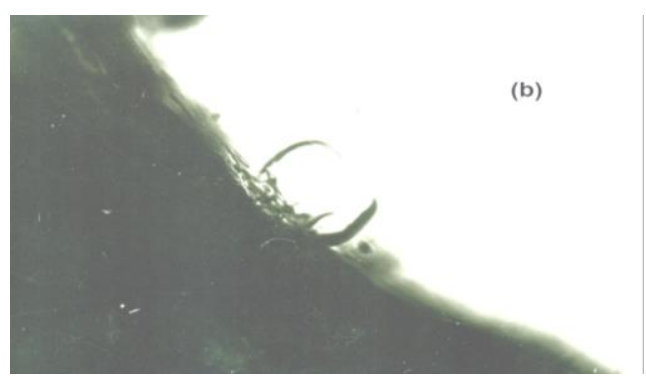

Fig. 3. Development of chamomile glandular hair on legulate floret (x400).

a) Young glandular hair.

Chamomile belongs to the plants which exhibit considerable variability in the content of essential oil during their development and the biosynthesis of sesquiterpenes appears to be associated with the ontogenesis of the plants (Franz et al., 1978 b, and Arak et al., 1980 b). Maximum chamazulene content in the anthodia was found out by Gluecknerova and Blazek (1965), when one third of the tubular flowers were open. Ruminska (1965) established the maximum b) Fully developed glandular hair.

chamazulene content in the anthodia with one half of the flowers open, with an abrupt decrease in the following phases.

Schantz and Salonen (1966) showed that the content of chamazulene in the essential oil was enhanced in developing anthodia. Stieber et al. (1979) found the maximum chamazulene content in the fully developed anthodia. 
In the course of the life of the plant, Karawaya et al. (1968) showed that the prochamazulene value and chamazulene percentage increased slightly and attained their maximum in the third collection, then decreased gradually towards the end of the flowering period.

Other changes in the composition of the essential oil during flowering in untreated plants have been reported by many investigators (Stieber et al., 1979, Araki et al., 1980 b, Repcak et al., 1980 and Vaverkova and Herichova, 1980).

Concerning changes in the essential oil composition as a result of the treatments with growth regulators, it was found that at each flower collection throughout the growing period the chamazulene content of the chamomile essential oil was decreased by $\mathrm{GA}_{3}$ treatment only at the $3^{\text {rd }}$ collection but increased at the $5^{\text {th }}$.

However, Ethrel had no influence on the quality of the essential oil of flower heads. It seems worthwhile to carry out more intensive studies on the mode of action of these and other plant growth regulators to clarify their influence on the growth and flowering pattern, on the ontogeny of the oil glands, and on the biosynthesis of the essential oil.

\section{CONCLUSION}

Oil quality depends mainly on the chamazulene content. In this respect, $\mathrm{GA}_{3}$ reduced it to one tenth of the control at the $3^{\text {rd }}$ picking. It can e concluded that the greatest benefit for chamomile production can be expected from Ethrel which caused the greatest increase in flower and essential oil yield without lowering the chamazulene content of the oil at the $3^{\text {rd }}, 4^{\text {th }}$ and $5^{\text {th }}$ picking dates.

\section{REFERENCES}

Arak, E.; Tammeorg, I. and Myaeorg, U. (1980 b). Dynamics of some components of chamomile essential oil. Refertivnyi Zhurnal 10.55.761.

Franz, Ch.; Hoelzl, J. and Voemel, A. (1978 b). Variation in the essential oil of Matricaria chamomilla L. depending on plant age and stage of development. Acta Horticulturae, 73: 229-238.

Gluecknerova, E. and Blazek, Z. (1965). The localization of the main active substances in chamomile flower heads. Farm. Obzor, 34(3): 148-154.
Hoelzl, J. and Demuth, G. (1975). Influence of ecological factors on the composition of the essential oil and the flavones in Matricaria chamomilla of different origins. Planta medica, 27: 37-45.

Isaac, O. (1974). Fortschritte in der Kamillenforschung Dtsch. Apoth. Ztg. 114(7): 255-260.

Karawya, M.S.; Awaad, K.E.; Svab, J. and Fahmy, T. (1968). A histochemical study of Matricaria chamomilla L. Planta medica, 16: 166-173.

Lassanyi, Z.; Stieber, G. and Tyihak, E. (1978). Investigations into the volatile oil secretory system of chamomillae anthodium. I. The histochemical analysis of glandular hairs. Herba Hungarica, 17(2): 31-42.

Reichling, J.; Becker, H. and Draeger, P.D. (1978). Essential oil of herbicides in chamomile cultivation. Acta Horticulturae, 73: 331-338.

Repcak, M.; Halasova, J.; Honcariv, R. and Podhradsky, D. (1980). The content and composition of the essential oil in the course of anthodium development in wild chamomile (Matricaria chamomilla). Biologia Plantarum. 22(3): 183191.

Ruminska, A. (1965). Der Einfluss des Entwicklungsstadiums auf die chemische Zusammensetzung (einschliesslich einiger morphologischen Merkmale der Blutenkoerbichen) von Achillea millefolium L. und Matricaria chamomilla L. Wissenschaftliche Zeitschrift der Karl-Mark-Universitaet Leipzig. 14: 429-433.

Schantz, M.V. and Salonen, R. (1966). Untersuchung ueber den Oelgehalt und die Gesamtazulenemenge waehrend der Entwicklung der Bluetenkoerbchen von in Finnland wild wachsender Kamille (Matricaria chamomilla L.). Scientia Pharmazentica. 34(3): 177-184.

Stieber, G.; Lassanyi, Z. and Tyihak, E. (1979). Investigations into the volatile oil secreting system of the chamomillae anthodium. II. Changes in the prochamazulene content of glandular hair in the chamomile flower during ontogeny. Herba Hungarica, 18(1): 27-39.

Vaverkova, S. and Herichova, A. (1980). Histochemical proof of prochamazulene at different stages of flower development in Matricaria chamomilla L. Biologia, 35(10): 753-757.

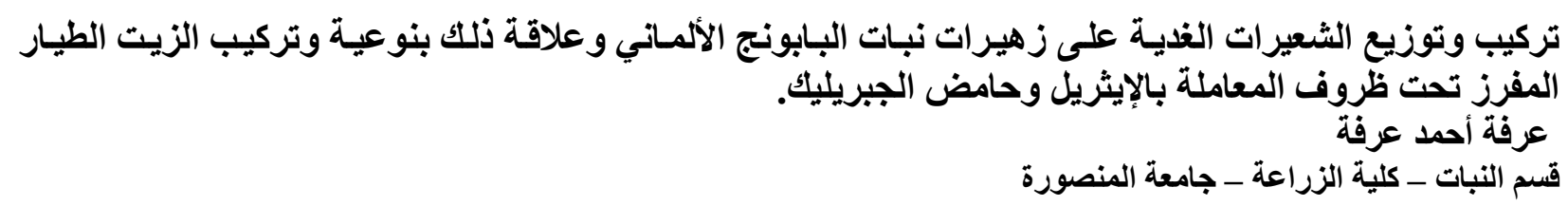

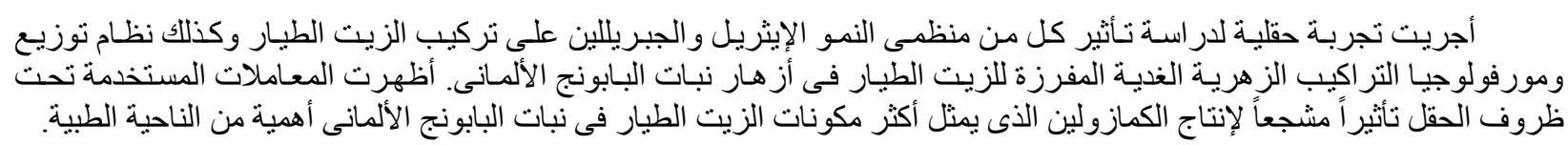

